\title{
A Case of Mistaken Identity
}

\section{Julian Petley}

I've just visited an organisation which was so afraid of physical attack that it dared not put its name at the entrance of its office building. It had recently published a report, distorted and inflammatory press coverage of which had put the organisation under siege and made its employees the recipients of hundreds of abusive and threatening phone calls, e-mails and letters. Along with the death threats came sentiments such as these: 'to show you what I think of your report, I'm going out of my house right now, and I'm going to slit the throat of the first Paki I meet'.

The organisation was the Runnymede Trust, the report was The Future of MultiEthnic Britain, and the newspaper responsible in the first instance for flood of hostile and mis-informed coverage was the Daily Telegraph.

The trouble began on 10 October 2000, when the Telegraph ran a front page article by its Home Affairs editor, Philip Johnston, headed 'Straw wants to rewrite our history', with the strap line '"British" is a racist word, says report'. The article opens with the words: 'Britain should be formally recognised as a multi-cultural society whose history needs to be "revised, rethought or jettisoned", says a report that has been welcomed by ministers', and continues: 'The inquiry was set up three years ago by the Runnymede Trust, a race equality think tank, and launched by Jack Straw, Home Secretary. Its report, to be published tomorrow, defines the UK as "a community of communities" rather than a nation. It says the description of its inhabitants as British "will never do on its own", largely because the term has "racist connotations"'.

These few lines contain no less than five major errors, but they were to determine the way in which not only the Telegraph but other papers were to cover the report over subsequent days. Apparently the decision to highlight the report was a last minute one, taken by the editor Charles Moore himself, which may account in part for some of the errors. However, the tone of its reporting can have nothing to do with the pressure of imminent deadlines. 
Firstly, and most seriously, the report nowhere says that the term 'British' has 'racist connotations'. What it actually says is this: 'Britishness, as much as Englishness, has systematic, largely unspoken, racial connotations. Whiteness nowhere features as an explicit condition of being British, but it is widely understood that Englishness, and therefore Britishness, is racially coded'. It notes that for Asians, African-Caribbeans and Africans 'Britishness is a reminder of colonisation and empire, and to that extent is not attractive' but adds that, although 'Britishness is not ideal ... at least it appears acceptable, particularly when suitably qualified - Black British, Indian British, British Muslim, and so on'. However, since the Telegraph article, and subsequent ones in the same paper, repeatedly substitute the word 'racist' for 'racial' one can only assume that the editor takes them to mean the same thing, in which case he would also be bound to agree that the statement of fact: 'The Telegraph is a national newspaper' is the same as the value judgement: 'The Telegraph is a nationalist newspaper'.

Secondly, the report does not define the UK as a community of communities rather than a nation but simply uses the phrase as a means of picturing how Britain could, and in its opinion, should, develop. It does this as a way of trying to displace a different picture: Britain as consisting of one large homogenous majority plus various small minorities. But nowhere is it suggested that this is how Britain should be renamed. This is what the report actually says: 'It would be consistent with the dictionary definition [of community] to envisage Britain as a community whose three principal constituent parts are England, Scotland and Wales, and to envisage each of the constituent parts as a community, as also each separate region, city, town or borough. Any one individual belongs to several different communities'.

Thirdly, the Telegraph makes the elementary mistake of conflating the United Kingdom and the British Isles. What the report actually says is this: "many acknowledge that ideally there needs to be a way of referring to the larger whole of which Scotland, Wales and England are constituent parts. But the nation state to which they belong is the United Kingdom not Britain ... The Good Friday Agreement of 1999 implies that there should be a sense of affiliation to the supranational identity known as "these islands" [i.e. including the Republic of Ireland]. Perhaps one day there will be an adjective to refer to this entity, similar in power perhaps to the unifying word "Nordic" in Denmark, Finland, Norway and Sweden. But for the 
present no such adjective is in sight. It is entirely plain, however, that the word "British" will never do on its own'. This is self-evidently true as applied to the British Isles, as in the report, and as Philip Johnston would no doubt discover were he to pop into a bar in, say, a nationalist part of Derry and tell the assembled company that they were all British. Applied to the United Kingdom, however, it becomes quite a different proposition, and one which the report never puts forward.

Fourthly, to state that the report argues that British history needs to be rewritten, revised, rethought or jettisoned is selective to the point of serious distortion. The passage to which this charge refers merely argues that if Britain is to acquire 'a broad framework of common belonging' in which 'cultural diversity is cherished and celebrated' then 'one critical prerequisite is to examine Britain's understanding of itself. How are the histories of England, Scotland and Wales understood by their people? What do the separate countries stand for, and what does Britain stand for? Of what may citizens be justly proud? How has the imagined nation stood the test of time? What should be preserved, what jettisoned, what revised or reworked? How can everyone have a recognised place within the larger picture?'. Thus what the Telegraph presents as a bald statement is actually a serious of questions for discussion, and the report's remarks about pride in and preservation of aspects of British history are conveniently ignored.

Finally, and perhaps most importantly, is the role which the paper allots to Jack Straw in the publication of the report. The headline is unequivocal - 'Straw wants to rewrite our history' - and unequivocally wrong, and there is nothing in the article that remotely substantiates such a wild accusation. In fact, Straw's role in the report was limited to launching it when Labour first came to power. However, it is clear, and becomes ever more so as the controversy develops, that it is Straw in particular and Labour in general which are the Telegraph's real target. Thus the article states that: 'although the Government finds some of the report's recommendations unwelcome, particularly on asylum and immigration policy, it apparently accepts the thrust of its conclusions', and Home Office minister Mike O'Brien is quoted to the effect that: 'This is a timely report which adds much to the current debate on multi-ethnic Britain. The Government is profoundly committed to racial equality and the celebration of 
diversity. We are a multi-cultural society'. Similarly the editorial, headed 'The British race', begins: 'It is astonishing that ministers should have welcomed the sub-Marxist gibberish' contained in the report, and concludes that: 'Under the guise of "multiculturalism", they are advancing their old Marxist dislike of any national culture. It is shameful that the Government should have been cowed into going along with this rubbish'.

It's worth pointing out that the passages of the report which so enraged the Telegraph occupy just over three pages of its total of 417 . Nonetheless, the effect of its reporting on much of the rest of the press was galvanic. The next day, for example, the Mail ditched the front page article it had intended running and replaced it with one headed 'Racism slur on the word "British"; the inside pages were also changed to include an extremely unflattering run-down of members of the commission which produced the report, a lengthy editorial ('What an insult to our history and intelligence'), an essay by Paul Johnson and a hostile commentary by Raj Chandran of the Commision for Racial Equality ('An insult to all our countrymen'). Similarly, the same day's Sun ran a lengthy piece by its political editor Trevor Kavanagh headed 'Ministers welcome report which says "British" is a racist word', an indignant editorial which urged Straw to 'stick this report in the bin', and a comment piece ('It's ridiculous') by the athlete Daley Thompson. Indeed, such was the rat-pack mentality of most of the press on this issue that even the supposedly liberal Guardian joined the fray Thus the headline of its main article on 11 October reads: 'British tag is "coded racism"', although the term 'coded racism' appears neither in the report nor in the article itself. The paper also ran a broadly welcoming editorial entitled 'Prescription for harmony'. However, this also carries the strap 'But race report is spoilt by bad idea' - this appears to be 'dropping Britain', which is nowhere recommended by the report. The paper does, however, redeem itself to some extent with an article by Gary Younge which opens with the most pertinent words written during the whole of this furore: 'if you really want to take the racial temperature in Britain, you would be better off examining the reactions to the report on multi-ethnic Britain than the report itself'. The Mirror, Star, Times and Evening Standard also took the 'racist' bait, and only the Independent and Express avoided this line entirely and succeeded in dealing with the report wholly in its own, as opposed to the Telegraph's, terms. 
Over the next few days, the commissioners were to find themselves described as 'worthy idiots' and 'purblind, self-indulgent and insensitive' in The Times, 'middleclass twits' in the Star, 'crack-brained' and 'a bunch of cranks and losers' in the Telegraph, 'left-wing wafflers' in the Evening Standard, and a 'second-rate unrepresentative clique' composed of 'disconnected, whining liberals' in the Mail. The report itself was condemned variously as 'gibberish, 'balderdash', 'ridiculous', 'burblings' and 'rhubarb' in the Telegraph, 'right-on trendy trash' and a 'pile of cack' in the Star, and 'tendentious rubbish' in the Mail. According to the Sun, if the report's recommendations were implemented, 'children will be told lies about their history and encouraged to feel ashamed of their country'. Meanwhile, the Telegraph gave over its letters pages to correspondence much of which would not have been out of place in the official publications of the British National Party or the National Front, in which rage and bile were relieved only by galumphing attempts at 'humour' which made Private Eye's spoof e-mails from 'Mike Giggler' side-splitting by comparison.

The immediate purpose of all this fury and vituperation was, quite clearly, to force Jack Straw to distance himself from the report. However, as mentioned earlier, it is difficult to wade through this endless editorialising without coming to the conclusion that the report was little more than a pretext to attack everything about the Labour government which the Right detests. Thus, for example, the Mail editorial on 11 October argued that: 'In ordinary circumstances, the report's clunking prose, flawed argument and lamentable ignorance of history would be risible. But this exercise was launched by Home Secretary Jack Straw. Its conclusions have been welcomed by the Home Office. If not yet official policy, the report reflects New Labour attitudes'. It concluded: 'the tragedy is that this self-serving exercise by a second-rate, unrepresentative clique is being embraced by Ministers who claim to represent Britain and the British people, but have plainly lost confidence in both'. Similarly the essay in the same day's paper by Paul Johnson argued that: 'the Runnymede Trust report, calling for a total re-write of our history and the banning of such terms as "English" and "Britain" as racist, looks like the first move in a New Labour brainwashing exercise designed to destroy our sense of nationhood'. 
Further proof was provided by the Telegraph 12 October (which devoted no less than six self-congratulatory pieces to the furore which it had ignited) in a column by Boris Johnson, whom the paper still coyly insists on billing as the editor of the Spectator rather than as the Tory MP-in-waiting for Henley on Thames, in which he opines that 'this is a war over culture, which our side could lose'. One of the major points at issue in this war is, of course, the Macpherson report into the death of Stephen Lawrence, which earned Straw the absolutely undying hatred of papers such as the Telegraph. And, sure enough, this hoves into view into its editorial 'Don't diss Britannia' (a headline which must have mystified most of its readers). This argues that: 'Mr Straw is unconvincing when he dons the mantle of John Bull. He has pulled a similar stunt before - making much of rowing back from some of the wilder shores of the Macpherson report on "institutionalised racism" in the Metropolitan Police'. Of that report, the editorial alleges that 'Mr Straw was able to smuggle it past the public by playing the role of commonsense watchdog. So it is with this commission. Mr Straw and Number 10 have distanced themselves from the report's most offensive comments, but they have not distanced themselves from its substantive proposals'. The editorial concludes that: 'the Conservatives now have an excellent chance to make good their past silence on Macpherson. They must expose the Government's collusion in this attempt to destroy a thousand years of British history'.

Similarly, the same day's Sun, in an editorial headed 'A disgrace', used the report to lambast one of its favourite Labour targets: the 'metropolitan elite': 'We cannot tolerate an officially sanctioned Government report that says these things. The fact that the Home Secretary hasn't binned the ludicrous 'British is racist' report is a disgrace. What on earth is going on? Too many in the Government don't seem to like Britain ... The new Establishment - the metropolitan elite - have no confidence in the British. They simply do not understand that patriotism is a good thing. In America, many homes have flags outside. Here, we have a government that appears to think its own people are racists. What a scandal. What a state of affairs'.

The overtly party-political thrust of the Telegraph's campaign was further emphasised on 13 October when it ran a lengthy piece by William Hague entitled: 'Why I am sick of the anti-British disease'. This began: 'in the 1970s, the threat from the Left was an economic one and came in the form of militant unions, punitive taxes and picket lines. 
We called it the British disease. In 2000, the threat from the Left is as much a cultural one, and manifests itself in the tyranny of political correctness and the assault on British culture and history. We should call it the anti-British disease. Never has this cultural threat been more clearly expressed than in the report by the Runnymede commission'. According to Hague: 'The report's recommendations may range from the potty to the sinister, but it is the overall thinking that gave rise to creating the commission in the first place that represents the real threat. For when the commission says that "Britishness has systematic racial connotations", it is betraying a wider agenda of the New Labour elite. These people believe that the very idea of "Britain" is irredeemably tainted by the combination of our imperial history, a concept of nationality that is past its sell-by date and public institutions that are "institutionally racist"'. The report is then lumped together with 'Cool Britannia', devolution, 'Europe' and every other hate object in Tory demonology to show that we have a government 'led by a Prime Minister embarrassed about the country he lives in and the people who elected him'.

And just in case anybody was still unsure of the message, the paper also carried an editorial, headed 'Turning point at Runnymede'. This again explicitly links the Runnymede document with the Macpherson report, of which it states that 'no more disgracefully unfair document has ever been produced by a judge in modern British history'. However: 'its bigoted conclusions were accepted with only a whimper of protest by the institutions it criticised. The bullying of the "anti-racists" had won. At last, though, something is changing. To the obvious shock of the comfortable peers, millionaires' wives and public sector grandeees who lent their names to the report, people are starting to say that they will not take any more. The report's suggestion that the word "British" is racist has finally frightened even those ministers who thought that they could never go wrong by appeasing such doctrines. Jack Straw and Tony Blair have suddenly changed from their usual approval, and have reached instead for a Union flag in which to wrap themselves. It doesn't fit very well, but it is interesting that it has happened at all'.

What the Telegraph is referring to here are, of course, the official responses by the Home Office and No. 10 to the actual publication of the report on October 11. However, even the press reports of these are spun to the point of distortion. What 
Tony Blair's official spokesman, i.e. Alistair Campbell, actually said was:

'Britishness to us is about issues as varied as how you manage the economy, the approach you take to issues like unemployment, your vision of society. Britishness is served not by ethnic nationalism, nor by the status quo plan adopted by our Conservative opponents - it's about how you develop and promote your values in a wider world'. This was interpreted by a Mail headline on 12 October as: 'Downing Street hits back over attack on our past', but that was as nothing compared to an article in the same day's Sun, headed 'Labour scorn for Brit pride', which somehow managed to interpret Campbell's words thus: 'Tony Blair's official spokesman put the boot into Britain yesterday - and laid bare New Labour's vision of our nation'.

Similarly, to read most of the press reports of what Jack Straw said at the launch of the report and then to read the entire speech (which can be found on the Commission's website at www.runnymedetrust.org/meb) is to read about two apparently different events. The tone of the reports can be gathered from headlines such as 'Straw beats very British retreat over race report' (Telegraph) and "'Proud to be British" Straw raps race report' (The Times), with even more friendly papers appearing to join in the fray with 'Race report angers "proud Briton" Straw' (Express) and 'Straw launches scathing attack on "unpatriotic" political left' (Independent), although in the case of the last two the articles themselves gave a much more balanced account of the event than the headlines would have led the reader to expect.

Most of Straw's lengthy speech is actually taken up with fulsome and clearly heartfelt praise for Runnymede's work over the years. Given the sheer amount of criticism directed at the report by the press, Straw was clearly left with absolutely no option but to respond to it. What he in fact did was to re-write at least parts of the speech which he had intended to deliver, and to delay publication of the Home Office's official 40page response. Equally importantly, key journalists were briefed by the Home Office in such a way as to accentuate the more critical aspects of the speech, and much of the resulting coverage shows how just how readily they accepted the officially spun line.

However, the positive parts of his speech (which also repeatedly praises the Lawrence Report) massively outnumber the few negative comments, which could be taken as its main point only by papers with a particular parti pris on the whole matter, or by 
journalists who believe all that they are told by spin doctors. Straw's criticisms are actually pretty mild stuff by comparison with his positive remarks, and come near the end of his speech. What he actually said was that he felt that 'the Commission were a little grudging in recognising what's been achieved already', that 'I frankly don't agree with the Commission' over its views on Britishness (which he explicitly contrasted with what the Telegraph alleged its views were), and, via a reference to George Orwell's famous remark that 'almost any English intellectual would feel more ashamed of standing to attention during God Save the King than of stealing from the poor box', that the task of moulding Britishness into a 'single shared identity was always going to be a challenge, but it was in my judgement made more difficult by those on the left who turned their backs on concepts of patriotism and who left the field to those on the far right'. And that's it, folks. Indeed, Straw's strongest criticism's were actually reserved for the Telegraph itself; the Independent (but no other paper) quoted him as being 'astonished' at its 'extraordinary intervention', but nowhere was reported his remark that it 'has had [emphasis added] a record of separating its news coverage which, on the whole, has broadly subscribed to the facts, from its opinion which is its business' - which last remark could be taken as implying that the Telegraph is rather more of a viewspaper than a newspaper. Nor did any paper see fit to print the unqualified praise for the report voiced on the same day by Baroness Amos, a government Whip in the Lords. In this respect, funeral orations such as those read by The Times on 12 October - 'the sheer force with which Jack Straw, the Home Secretary, distanced himself from the most controversial aspects of the Future of Multi-Ethnic Britain report yesterday shows that this document will not influence official thinking in the future' - come across not only as premature but as decidedly wishful thinking.

This story tells us a good deal about the nature of the British press, not least its political bias, the rat-pack nature of its journalism, and its susceptibility to spin - in the double sense that newspapers are both adept at spinning stories themselves and all too easily led by the nose. But, however objectionable the treatment of the report by the Telegraph, Mail and others, the story can be read as a victory for those papers, and for the Right in general, only if one accepts the terms in which its official reception was reported by those papers, which, as I have suggested, are far from accurate. Furthermore, the predominance of Right-wing, and specifically English nationalist, 
views in the press, and the virulence with which they are expressed, makes them appear much more widespread and predominant than they really are outside the bile ducts which pass for newspapers in this country. For, without wishing to sound too Hegelian about this, these people really are swimming against the tide of history, and deep down they probably know it. Most of what in The Future of Multi-Ethnic Britain gave Boris Johnson, Charles Moore, Paul Dacre, Trevor Kavanagh et al a blue fit would appear as entirely commonsensical to any first year student of history, politics, sociology or cultural studies, and is part of a long debate encompassing works as diverse as Benedict Anderson's Imagined Communities, Eric Hobsbawm's The Invention of Tradition, Linda Colley's Britons, Raphael Samuel's Island Stories and Theatres of Memory, Robert Hewison's The Heritage Industry, Patrick Wright's On Living in an Old Country, Jeremy Paxman's The English, Norman Davies' The Isles, Andrew Marr's The Day Britain Died and Mark Leonard's Britain TM, to name but a few. As Hugo Young put it in the Guardian 12 October, the hysteria with which the report has been greeted 'throws a revealing light on these frightened spokesmen for the old canons of Britishness. They can barely contain their rage at the notion of the national identity, along with its hierarchy of historic icons, perhaps needing to be updated'.

This is not to deny, however, that, given their prevalence in the press in particular, these spokesmen cannot do a great deal to make discussion of the much-needed modernisation of Britain as difficult as it could possibly be. One has only to look at how they have entirely prevented a debate of any kind at all about Britain's future role in the EU to see the success of their endless hectoring and bullying. It is clearly extremely difficult for any government to live with this daily diatribe which is liable at any time, as in the case of the Runnymede report, to blow up into a full blown assault in which truth is the first casualty, and liberal 'bien pensants' who read only the Guardian or Independent can have little idea of the sheer amount of raging reaction that daily erupts from many other newspapers. However, discussion of the future direction of Britain is far too important for its terms to be dictated by unelected, unrepresentative and unaccountable newspaper editors, nor do sermons about patriotism sit well in foreign-owned newspapers such as the Canadian Hollinger Group's Telegraph and the mongrel Murdoch-owned Sun. Nor can such discussion be simply avoided as too awkward. As Stuart Hall, one of the members of the 
commission, has forcefully put it: 'Britain always was and really is now a nation of nations. It cannot continue to conflate "Englishness" with "Britishness". Some commentators really do suppose that Britain will obliterate all trace of its imperial history, devolve government, integrate with the global economy, play an active role in Europe, treat all minority peoples as equal citizens - and retain its self-understanding intact since Magna Carta! This is not serious analysis, it is cloud cuckoo land. The question of Britishness is a timebomb which is ticking away at the centre of this society and it is either faced and confronted or it will explode in our face in ways which we do not wish'.

Julian Petley. 